\title{
Analysis of Neuron-Specific Enolase of Cerebrospinal Fluid and Post Mortem Serum of Blunt Head Trauma in Cause and Time of Death Determination
}

\author{
Rika Susanti ${ }^{1}$, Taufik Hidayat ${ }^{2}$ \\ \{rikasusanti@med.unand.ac.id ${ }^{1}$, taufikhidayat@med.unand.ac.id² \\ Forensic and Medicolegal Department, Faculty of Medicine, Andalas University, Padang
}

\begin{abstract}
Blunt head trauma is the highest cause of death in criminal crime. Various attempts have been conducted to find alternative substitutes for the autopsy to determine the cause of death. NSE levels have been used as biomarkers in blunt head trauma in a living patient. The purpose of this study was to analyze NSE levels of CSF and serum in cause and time of death determination. This study was an experimental study with a posttest only group design, with the treatment of death due to blunt head trauma compared to deaths from acute ketamine poisoning. The number of treatment groups was 8 , with samples of each group were 6 adult Sprague Dawley Rattus novergicus. NSE levels were examined at 0 hours, 1 hour, 2 hours and 3 hours after death. Analysis of NSE levels of CSF and serum in determining the cause and time of death was undertaken with the General Linear Model Repeated Measure test. We found increases in NSE levels of CSF and serum in both groups of deaths due to blunt head trauma and acute ketamine poisoning, and there was a significant difference between the two groups with $p=0.005$ of serum NSE levels. There was no significant difference in the time of death between NSE levels of CSF and serum. Overall, there are increases in NSE levels of CSF and serum in deaths due to blunt head trauma and acute ketamine poisoning.
\end{abstract}

Keywords: Blunt Head Trauma, NSE, Cause of Death, Time of Death Determination.

\section{Introduction}

Blunt head trauma is an important issue in forensic medicine as it is the most common cause of death due to criminal crime and is also known as the most numerous case of death in the world [1]. In 2002, the trauma caused 4.5 million deaths or 1 in 10 deaths worldwide. Various cases could induce a blunt head, yet the highest number is due to traffic accident [1],[2],[3].

In the case of investigation for criminal acts, determining the cause of death is very urgent for law enforcement officers. Determination of the cause of death should be conducted by performing an internal examination (autopsy), but the examination received much rejection from the public [7].

Autopsy rejection rates in Indonesia, especially in West Sumatra are very high. At M. Djamil Padang Hospital, almost $80 \%$ of families resisted autopsy, and the most common reason was they were unwilling the body manipulation. Autopsy refusal is not only happened in Indonesia, worldwide, but the number of autopsies also decreased by $40-50 \%$. According to Burton et al. and Corona et al. and Cit Stawicki et al., in the United States, the number of 
autopsies decreased by $41 \%$ of all bodies that should have been autopsied in 1960 to $5-23 \%$ [8],[9].

Conventional procedures to estimates of the time of death are often carried out by examining changes in the body of the victim, including bruising, corpse stiffness, temperature changes, decay, stomach contents of the body. According to Dimaio et al., all those parameters used are untrustworthy and inaccurate. Several studies related to the time of death estimation continue to be performed by more objective techniques such as biochemical, histology and serology examination of various body fluids and body tissues. The body fluids that are common to be studied are blood, vitreous, cerebrospinal fluid, pericardium fluid and synovial fluid [12],[17],[18],[19].

Head injuries will cause several abnormalities such as hypoxia/brain ischemia, brain edema, metabolic disorders, changes in vascular permeability, reduced blood flow, inflammation, extensive axonal injury and increased intracranial pressure [27],[28]. All the changes that occur will cause damage or even death from other cells and brain tissue, which cell damage will cause an increase in several enzymes. Increased enzymes in head trauma have been used as biomarkers in clinical settings.

Neuron-specific enolase (NSE) is the main glycolytic enzymes found in the cytoplasm of neurons and also can be found in small amounts on platelets and red blood cells. Specific enolase neurons are a marker of neuronal death, and they increase after head trauma at all severity degrees. Elevation of serum NSE levels is correlated to the increase in intracranial pressure [29][33].

In this study, NSE levels in cerebrospinal fluid and postmortem serum in mortality due to blunt head trauma and death due to acute ketamine poisoning were being correlated to the determination of cause and time of death.

\section{Method}

This research was an experimental study with a post-test only group design. The treatment to treatment group rats was conducting blunt trauma to the head and euthanasia by injecting lethal dose ketamine, then undergoing an enzyme examination after the rat died. Measurements of enzyme levels for both groups were carried out at 0 hours after death, 1 hour after death, 2 hours after death and 3 hours after death.

\section{Result}

Cerebrospinal fluid NSE levels in deaths due to blunt head trauma and death from acute ketamine poisoning were described in Table 1.

Table 1. CSF NSE levels in deaths from blunt head trauma and acute ketamine poisoning based on the time of death.

\begin{tabular}{llll}
\hline Time of death & Group & $\mathrm{n}$ & Mean $\pm \mathrm{SD}(\mathrm{ng} / \mathrm{ml})$ \\
\hline \multirow{2}{*}{0 hours } & Acute ketamine poisoning & 6 & $29.9 \pm 8.4$ \\
\cline { 2 - 4 } & Blunt head trauma & 6 & $37.6 \pm 7.6$ \\
\hline 1 hour & Acute ketamine poisoning & 6 & $18.1 \pm 6.9$ \\
\hline
\end{tabular}




\begin{tabular}{clcc} 
& Blunt head trauma & 6 & $24.6 \pm 11.0$ \\
\hline \multirow{2}{*}{2 hours } & Acute ketamine poisoning & 6 & $36.2 \pm 14.5$ \\
\cline { 2 - 4 } & Blunt head trauma & 6 & $51.5 \pm 20.6$ \\
\hline \multirow{2}{*}{3 hours } & Acute ketamine poisoning & 6 & $37.3 \pm 24.3$ \\
\cline { 2 - 4 } & Blunt head trauma & 6 & $22.2 \pm 7.0$ \\
\hline
\end{tabular}

In Table 1, the mean of CSF NSE levels was higher in deaths due to blunt head trauma than deaths due to acute ketamine poisoning at 0 hours, 1 hour and 2 hours. Whereas at 3 hours after death, CSF NSE levels were higher in deaths due to acute ketamine poisoning than deaths due to blunt head trauma.

To see a graph of changes in CSF NSE levels based on the time of death and method of death can be seen in Figure 1.

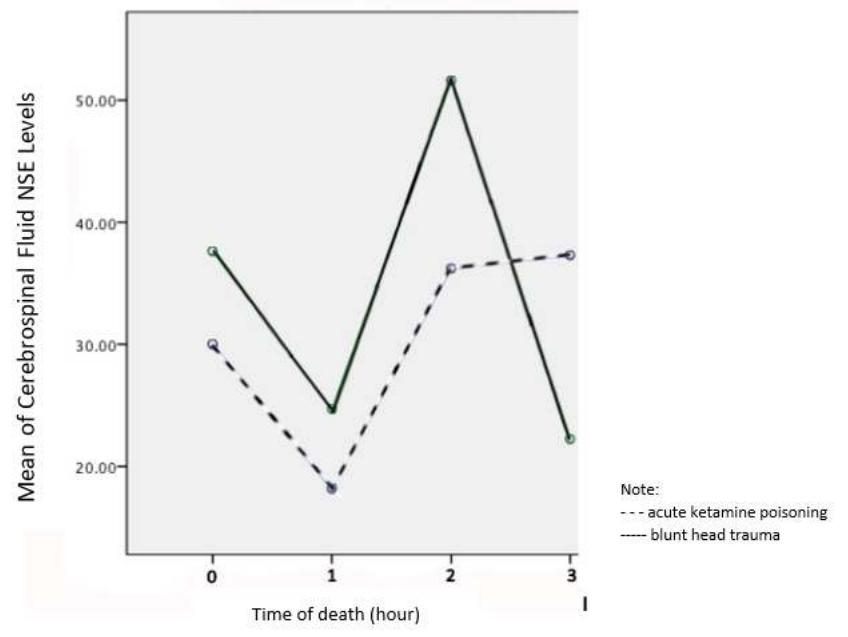

Fig. 1. Changes in LCS NSE levels based on time and method of death.

To see whether the data is normally distributed, a normality test was conducted following Shapiro Wilk, $\mathrm{p}>0.05$ in 6 data groups and $\mathrm{p}<0.05$ in the death data group after an hour blunt head trauma and death after 3 hours acute ketamine poisoning. It is concluded that data is not normally distributed. Therefore, the General Linear Model (GLM) test requirements for repeated observations of the two groups are not fulfilled.

To see the difference in CSF NSE levels between deaths due to acute ketamine poisoning and the death due to blunt head trauma at 0 hours and 2 hours (normal data distribution), an unpaired t-test was performed.

Table 2. Differences in LCS NSE Periods of group manner of death.

\begin{tabular}{lllll}
\hline Time of death & Manner of death & $\mathrm{n}$ & Mean $\pm \mathrm{SD}(\mathrm{ng} / \mathrm{ml})$ & $\mathrm{P}$ \\
\hline \multirow{2}{*}{0 hours } & Acute ketamine poisoning & 6 & $29.9 \pm 8.4$ & \multirow{2}{*}{0.132} \\
\cline { 2 - 4 } 2 hours & Blunt head trauma & 6 & $37.6 \pm 7.6$ & \multirow{2}{*}{0.166} \\
\cline { 2 - 5 } & Acute ketamine poisoning & 6 & $36.2 \pm 14.5$ & \\
\cline { 2 - 4 } & Blunt head trauma & 6 & $51.5 \pm 20.6$ & \\
\hline
\end{tabular}


In Table 2, the unpaired t-test for 0 hours obtained $p=0.132$ and 2 hours obtained $p=0.166$. It was concluded that there was no significant difference in CSF NSE levels in deaths from acute ketamine poisoning and death due to blunt head trauma at 0 hours and 2 hours of the time of death.

Serum NSE levels in deaths due to blunt head trauma and death due to acute ketamine poisoning can be observed in Table 3 .

Table 3. Serum NSE levels in deaths due to blunt head trauma and acute ketamine poisoning based on time of death.

\begin{tabular}{llll}
\hline Time of death & Kelompok & $\mathrm{n}$ & Mean $\pm \mathrm{SD}(\mathrm{ng} / \mathrm{ml})$ \\
\hline \multirow{2}{*}{0 hours } & Acute ketamine poisoning & 6 & $4.6 \pm 0.6$ \\
\cline { 2 - 4 } & Head blunt trauma & 6 & $4.7 \pm 0.3$ \\
\hline \multirow{2}{*}{\begin{tabular}{l} 
hour \\
\multirow{2}{*}{ hours }
\end{tabular}} & Acute ketamine poisoning & 6 & $5.3 \pm 0.4$ \\
\cline { 2 - 4 } & Head blunt trauma & 6 & $5.1 \pm 0.7$ \\
\hline \multirow{2}{*}{3 hours } & Acute ketamine poisoning & 6 & $6.7 \pm 0.2$ \\
\cline { 2 - 4 } & Head blunt trauma & 6 & $5.7 \pm 1.4$ \\
\hline
\end{tabular}

In Table 3, the mean of serum NSE levels of acute ketamine poisoning was higher in deaths from than deaths due to blunt head trauma, except at 0 hours of the time of death.

In Figure 2, a graph shows changes in serum NSE levels based on time and method of death.

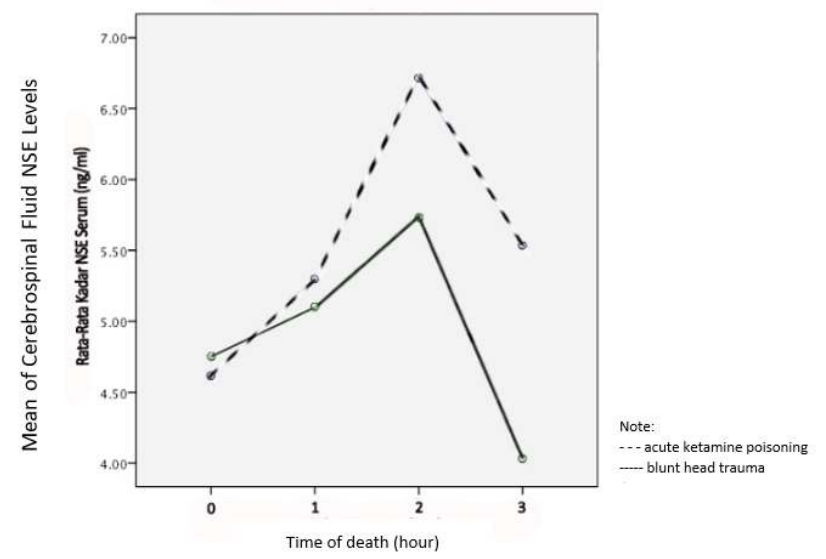

Fig. 2. Changes in serum NSE levels based on time and manner of death

Furthermore, a normality test was performed by Shapiro Wilk, obtained p-value $>0.05$ in all groups of data, so it was concluded that data were normally distributed.

To see differences in serum NSE levels based on time and manner of death, the General Linear Model (GLM) test was performed for repeated observations of the two groups. 
Table 4. Multivariate test results for changes in serum NSE levels based on time of death and method of death

\begin{tabular}{lll}
\hline & F & P \\
\hline Time of death $(0,1,2,3$ hours) & 6.438 & 0.016 \\
\hline Manners of death (acute ketamine poisoning, blunt head trauma) & 4.061 & 0.037 \\
\hline
\end{tabular}

In the multivariate test results, there were significant differences in serum NSE levels based on the time of death with a value of $p=0.016$. There were significant differences in serum NSE levels in deaths due to acute ketamine poisoning with death due to blunt head trauma $(p=0.037)$.

The difference in serum NSE levels based on the time of death both in the death group due to blunt head trauma and death due to acute ketamine poisoning can be observed in the result of tests of within-subject contrasts in Table 5.

Table 5. Changes in serum NSE levels based on time of death.

\begin{tabular}{lll}
\hline Comparison of time of death & $\mathrm{F}$ & $\mathrm{p}$ \\
\hline 1 hour vs 0 hours & 3.079 & 0.110 \\
\hline 2 hours vs. 0 hours and 1 hour & 17.422 & 0.002 \\
\hline 3 hours vs. 0 hours, 1 hour and 3 hours & 8.208 & 0.017 \\
\hline
\end{tabular}

In Table 5, the test results in accordance with the measurement of time of death for deaths due to acute ketamine poisoning and death due to blunt head trauma showed no significant difference in serum NSE levels between 1 hour mortality and 0 hours $(\mathrm{p}>0.05)$, and there were significant differences in serum NSE levels between 2 hours of death time and 0 hours and 1 hour; and between the time of death 3 hours and 0 hours, 1 hour and with 2 hours $(\mathrm{p}<0.05)$.

Table 6. Changes in serum NSE levels affected by manners of death

\begin{tabular}{lll}
\hline Manner of death & $\mathrm{F}$ & $\mathrm{p}$ \\
\hline $\begin{array}{l}\text { Acute ketamine poisoning } \\
\text { Blunt head trauma }\end{array}$ & 13.179 & 0.005 \\
\hline
\end{tabular}

Table 6 is the result of the test of between-subject effects, showed $p=0.005(p<0.05)$ which meant there were significant differences in serum NSE levels between deaths due to acute ketamine poisoning and death due to blunt head trauma, where serum NSE levels were higher in deaths due to acute ketamine poisoning.

\section{Discussion}

The rate of CSF NSE in the group of death due to blunt head trauma was higher than in the group of deaths due to acute ketamine poisoning, except in 3 hours after death. There was not any significant difference in CSF NSE levels in deaths from acute ketamine poisoning and death due to blunt head trauma. In both groups, CSF NSE levels increased from normal. 
Research by Hans et al. obtained LCS NSE levels in cisterna magna samples in normal living mice with $<4.4 \mathrm{ng} / \mathrm{ml}$. According to Palmio, CSF NSE levels in the normal human population are 17.34,6 ng/l. Casimiro et al. in his study of the normal population, found CSF NSE levels were twice as high as serum NSE levels. Ondruschka et al. concluded that the higher the NSE level, the smaller the time of death with trauma. According to Siman, NSE levels are used as a marker of acute brain damage. An increase in NSE levels corresponds to the severity of brain damage [31,35,41-47].

The average change in LCS NSE levels based on the time of death cannot be used to estimate the time of death.

In this study, the mean postmortem serum NSE levels were higher in deaths due to acute ketamine poisoning than deaths due to blunt head trauma, except at 0 hours of death. There were significant differences in serum NSE levels in both groups. NSE levels of deaths due to acute ketamine poisoning and death due to blunt head trauma increased from normal.

Chekhonim et al. found normal serum NSE levels in mice ranged from $1.7 \pm 1.3 \mathrm{ng} / \mathrm{ml}$. Research by Skogseid et al., Zahra et al. and Olivecrona et al. concluded, in patients who had a head injury an increase in serum NSE levels were related to the severity of brain injury. According to Skogseid et al., NSE is a marker of acute brain damage $[34,48]$.

In the table of within-subject contrasts test, it was concluded that changes in serum NSE levels based on the time of death could not be used as a basis for estimating the time of death because changes in serum NSE levels were not significant at all levels of time of death with the time of previous death.

Enolase is the main enzyme for energy metabolism found in all cell cytoplasm [49]. NSE involved in the glycolysis pathway in the change of 2-phosphoglycerate to phosphoenolpyruvate at the ninth stage of the glycolysis process. In head injury, there is an increase in intracell calcium levels which will cause intracellular catabolic processes [31,42,50-52].

According to Brunswick et al. and Zetterberg et al., increased activity of various membrane pumps to restore ion balance causes increased glucose consumption, reduction in energy storage, $\mathrm{Ca} 2$ + enter mitochondria, imbalance of oxidative metabolism and glycolysis with lactate production, so that in this process, NSE cannot function $[36,53]$. In the case of neuron damage, the excessive enzyme is not functional because the aerobic glycolysis process decreases.

In this study, it was found that NSE levels were higher than normal levels with 6 times higher than serum levels of NSE. In a study of normal population, CSF NSE levels were twice higher than serum NSE levels [54]. CSF NSE levels increased 6 times higher than serum possibly due to blood contamination in CSF fluid when sampling, high levels of LCS NSE indicated that NSE was released in brain trauma. NSE is a marker of increased neuronal trauma after focal or diffuse ischemia [49]. In this research, NSE levels increases were mostly due to neuronal cell damage by direct trauma. Besides, the increases also influenced by the process of cell damage that began to occur in secondary injuries. In cell damage setting, NSE neurons are released out of the cytoplasm [50]. Neuronal damage and impaired blood-brain barrier integrity can be detected by NSE released into CSF and then into the blood. So it can be concluded that NSE levels can be used as biomarkers in deaths due to blunt head trauma $[49,50]$. 


\section{Conclusion}

There was an increase in postmortem cerebrospinal fluid NSE level in deaths due to blunt head trauma and acute ketamine poisoning, but there was no significant difference in correlation to the time of death. There was an increase in serum postmortem NSE level in deaths due to blunt head trauma and acute ketamine poisoning, but there was no significant difference in correlation to the time of death.

\section{References}

[1] Puvanachandra P, Hyder AA, 2009. The burden of traumatic brain injury in Asia: A call for research. Journal of Neurological Science 4.(1).27-32.

[2] Riyani W, Suhardi, Permana M, 2009. Pola dan determinan sosiodemografi cedera akibat kecelakaan lalu lintas di Indonesia. Majalah Kedokteran Indonesia 59(10) :464-472.

[3] Wagner AK, Arenth PM, Kwasnica C, Rogers EH, 2011. Traumatic brain injury. In Physical Medicine and Rehabilitation, $4^{\text {th }}$ ed, pp 1133-1175.

[4] Stippler M, 2012. Trauma of the nervous system: Craniocerebral trauma. In Bradley’s Neurology in Clinical Practice, $6^{\text {th }}$ ed, pp 942-956.

[5] Park E, Bell JD, Baker AJ, 2008. Traumatic brain injury: Can the consequences be stopped?. CMAJ 178: 1163-1170.

[6] Riandini IL, 2013. Gambaran luka korban kecelakaan lalu lintas yang dilakukan pemeriksaan di RSUP dr. M.Djamil Padang. Skripsi. Padang: Fakultas Kedokteran Universitas Andalas

[7] Treloar AE, 2009. Death sertification. In Finkbeiner WE, Ursell PC, Davis RC, Connolly A. Autopsy Pathology, Chapter 13, $2^{\text {nd }}$ ed. Saunders, an Imprint of Elsevier Inc.,pp 147-156.

[8] Kadarmo DA, 2005. Prosedur medikolegal penolakan otopsi ditinjau dari sudut pandang penyidik. Thesis. Jakarta: Fakultas Kedokteran Universitas Indonesia.

[9] Stawicki SP, Anggawal A, Dean AJ, Bahmer DA, Steinberg SM, Stehly CD, et al., 2008. Postmortem use of advanced imaging techniques : Is autopsy going digital?. OPUS 12 Scientiest 2(4): $17-26$

[10] Afandi D, 2009. Otopsi virtual. Majalah Kedokteran Indonesia 59(7): 327-332.

[11] Dix J, Calaluce R, Ernst MF, 1999. Guide to forensic pathology. Boca Raton London New York Washington DC: CRC Press.

[12] DiMaio DJ, Dimaio VJ, 1993. Forensic pathology. New York: CRC Press.

[13] Salam HFA, Shaat EA, Aziz MHA, Moneimsheta AA, Hussein HASM. 2012. Estimation of postmortem interval using thanatochemistry and postmortem changes. Alexandria Journal of Medicine 48: 335-344.

[14] Donaldson AE, Lamon IL, 2013a. Biochemistry changes that occur after death: Potential markers for determining postmortem interval. Journal PLOS ONE. Diakses dari http://www.plosone.org/article.com.

[15] Buras KL, 2006. Are enzymes accurate indicators of postmortem Interval? A biochemical analysis. Thesis, Departement of Geography and Anthropology.B.S., Louisiana State University.

[16] Shkrum MJ, Ramsay DA, 2007. Postmortem changes. In Forensic Pathology of Trauma. Totowa, New Jersey: Humana Press.

[17] Sheikh NA, 2008. Study of sodium \& glucose levels in cadaveric synovial fluid to estimate postmortem interval. Indian Journal of Forensic Medicine and pathology 1(3-4): 81-85.

[18] Shepherd C, 2003. Changes after death. In Simpson's Forensic Medicine, $12^{\text {th }}$ ed. London: Arnold, pp 37-48.

[19] Ahi RS, Garg V, 2011. Role of vitreous potassium level in estimating postmortem interval and the factors affecting it. Journal of Clinical and Diagnostic Research 5(1): 13-15. 
[20] Garg SP, Garg V, 2005. Serum enzymes changes after death and its correlation with time since death. J Indian Acad Forensic Med 32(4): 355-357.

[21] Sharma P, Jain S, Mathur R, Vyas A, 2012. A study of pericardial fluid enzymes activities after death and their correlation with post mortem interval. J Indian Acad Forensic Med 34(4):346349.

[22] Dalbir S, Rajendra P, 2009. Relationship between post mortem interval and the pericardial enzyme activities in subjects of chandigarh zone of India- A preliminary study. Journal of Indian Academy of Forensic Medicine 31 (1): 30-36.

[23] Priyanka S, Sheetal J, Rati M, Amit V, 2012. A study of pericardial fluid enzymes activities after death and their correlation with post mortem interval. Journal of Indian Academy of Forensic Medicine, 34(4): 346-349.

[24] Liao ZG, Quatrehomme G, Wu JW, 1994. Estimation of post-mortem interval based on the changes of phosphorylase activity in skeletal muscles. Acta Medicinæ Legalis 44: 156-159.

[25] Coe JI, 1993. Postmortem chemistry update. The American Journal of Forensic Medicine and Pathology 14(2): 91-117.

[26] Maeda H, Michiu T, Zhu BL, Ishikawa T, Quan L, 2009a. Analysis of cardiac troponins and creatine kinase $\mathrm{MB}$ in cerebrospinal fluid in medicolegal autopsy cases. Legal Medicine 11:266268 .

[27] Zacko JC, Hawryluk GWJ, Bullock MR, 2011. Neurochemical pathomechanisms in traumatic brain injury. In Winn HR., Yaumans Neurological Surgery, Chapter 327. Saunders, an Imprint of Elsevier Inc., pp 3305-3324.

[28] Defazio MP, Rammo RA, Robles JR, Bramlett HM, Dietrich WD, Bullock MR, 2013. The potential utility of blood derived biochemical markers as indicators of early clinical trends following severa traumatic brain injury. World Neurosurgery. Diakses dari http://dx.doi.org/10.1016/j.wneu.2013.01.015.com

[29] Berger RP, 2011. Biochemical markers of head trauma in children in child abuse and neglect: Diagnosis, treatment and evidence, pp 429-440.

[30] Borg K, Bonomo J, Jauch C, Kupchak, Stanton E, Sawadsky B, 2012. Serum level of biochemical markers of traumatic brain injury. ISRN Emergency Medicine 417313: 1-7.

[31] Ondruschka B, Pohlers D, Sommer G, Schober G, Schober K, Teupser D, et al., 2013. S100B and NSE as useful postmortem biochemical markers of traumatic brain injury in autopsy cases. Journal of Neurotrauma 30:1862-1871.

[32] Ingebrigtsen T, Romner B, 2003. Biochemical serum markers for brain damage: A short review with emphasis on clinical utility in mild head injury. Restorative Neurology and Neuroscience 21: 171-176.

[33] Woertgen C, Rothoerl RD, Holzschuh M, Metz C, Brawanski A,1997. Comparison of serial S100 and NSE serum measurements after severe injury. Acta Neurochir 139: 1161-1165.

[34] Skogseid IM, Nordby HK, Urdal P, Paus E, Lilleaas F, 1992. Increased serum creatine kinase BB and neuron specific enolase following head injury indicates brain damage. Acta Neurochir 115: 106-111.

[35] Herrmann M, Jost S, Kutz S, Ebert AD, Krafz T, Wunderlich MT, et al., 2000. Temporal profile of release of neurobiochemical markers of brain demage after traumatic brain injury is associated with intracranial pathology as demonstrated in cranial computerized tomography. Journal of Neurotrauma 17 (2) :113-122.

[36] Zetterberg H, Smith DH, Blennow K, 2013. Biomarkers of mild traumatic brain injury in cerebrospinal fluid and blood. Nat.Rev.Neurol. $9:$ 201-210.

[37] Li DR, Michiue T, Zhu BL, Ishikawa T, Quan L, Zhao D, et al., 2009. Evaluation of postmortem S100B levels in the cerebrospinal fluid with regard to the cause of death in medicolegal autopsy. Legal Medicine 11: 273-275. 
[38] Pai A, Heining M, 2007. Ketamine. Continuing Education in Anaesthesia Critical Care and Pain 7(2):59-63.

[39] Kalsi SS, Wood DM, Dargan PI, 2011. The epidemiology and patterns of acute and chronic toxicity associated with recreational ketamine use. Emerging Health Threats Journal 4(7107):110.

[40] World Health Organization. 2006. Critical Review of Ketamin.

[41] Hans P, Born JD, Albert A, 2008. Extrapolated creanine kinase BB isoenzyme activity in assessment of initial brain damage after severe head injury. J Neurosurg May 66(5):714-7.

[42] Palmio J, 2009. Seizure-related neuronal injury. A study of neuron-specific enolase, S-100B protein and tau protein. Dissertation, Faculty of Medicine of University of Tampere, Finland.

[43] Casmiro, Maitan SF, Pasquale D, Cova V, Scarpa E, Vignatelli L, 2005. Cerebrospinal fluid and serum neuron-specific enolase concentrations in a normal population. European Journal of Neurology 12: 369-374.

[44] Siman RG, 2013. Biomarkers. In Roux PDL, Joshua, Kofke WA, Monitoring in Neurocritical Care, chapter 18. Saunders, an Imprint of Elsevier Inc. pp 165-175.

[45] Naeimi ZS, Weinhofer A, Sarahrudi K, Heinz T, Csei V, 2006. Predictive value of S-100B protein and neuron specific-enolase as markers of traumatic brain damage in clinical use. Brain Injury, Taylor \& Francis May 20(5): 463-468.

[46] Oleveira COD, Ikuta N, Regner A, 2008. Outcome biomarkers following severe traumatic brain injury. Rev Bras Ter Intensiva 20(4): 411-421.

[47] Persson L, Hardemark HG, Gustafsson J, Rundsfrom G, Mendel-Hartvig I, Esscher T, et al., 1987. S-100 protein and neuron specific enolase in cerebrospinal fluid and serum: Markers of cell damage in human central nervous system. Journal of The American Heart Association18: 911-918.

[48] Chekhonim VP, Lebedev SV, Dmitrieva TB, Blinov DV, Gurina OI, Semenova AV, et al., 2003. Enzyme immunoassay of NSE and GFAP as the criterion of dynamic evaluation of rat blood brain barrier in perinatal hypoxic ischemic injury of the CNS. Bulletin of Experimental Biology and Medicine 136(3):261-265.

[49] Degiorgio CM, Rabinowicz AL, Correale J, Heck CN, Gott PS, Schreiber S, 2006. Neuron specific enolase in status epilepticus. In Wasterlain CG, Treiman DM, Editor, Status Epilepticus Mechanism and Management. Cambridge, United Stated of America: The MIT press, pp 169177.

[50] Finsterer, Exner M, Rumpold H, 2004. Cerebrospinal fluid neuron-specific enolase in nonselected patients. Scand J. Clin Lab Invest 64: 553 - 558.

[51] Brettschneider J, Petzold A, Süssmuth S,Tumani H, 2009.Cerebrospinal fluid biomarkers in Guillain-Barré syndrome - Where do we stand?. J Neurol 256:3-12.

[52] Sandler SJI, Figaji AA, Adelson PA, 2010. Clinical applications of biomarkers in pediatric traumatic brain injury. Childs Nerv Syst. 26: 205-213.

[53] Brunswick AS, Hwang BY, Appelboom G, Hwang RY, Piazza MA., Conolly ES, 2012. Serum biomarkers of spontaneous intracerabral hemorrhage induced secondary brain injury. Journal of the Neurological Science 327: 1-10.

[54] Casmiro, Maitan SF, Pasquale D, Cova V, Scarpa E, Vignatelli L, 2005. Cerebrospinal fluid and serum neuron-specific enolase concentrations in a normal population. European Journal of Neurology 12: 369-374.

[55] Kirino T, Brightman MW, Oertel WH, Schmechel DE, Marangost PJ, 1983. Neuron-specific enolase as an index of neuronal regeneration and reinnervation. The Journal of Neuroscience 3(5): 915-923. 